\title{
A conjuntura política brasileira e os destinos da educação integral: entrevista com José Luís Sanfelice
}

\author{
Antônio Carlos Maciel \\ Universidade Federal de Rondônia, Curso de Ciências Sociais, Programa de Pós-Graduação \\ em Educação, Professor. \\ http://orcid.org/0000-0003-0250-4213
}

Recebido em 30 de novembro de 2020

Aceito em 8 de março de 2021

Sobre o entrevistado:

José Luís Sanfelice é Licenciado e Bacharel em Filosofia pela Pontifícia Universidade Católica de São Paulo. Tem Mestrado em Filosofia da Educação e Doutorado em Educação na PUC-SP. Como docente atuou na PUC-SP, na PUC de Campinas (SP) e na Universidade Estadual Paulista "Júlio de Mesquita Filho" - UNESP, Campus de Marilia-SP. Ingressou na Faculdade de Educação da UNICAMP, em 1981, onde exerceu vários cargos até aposentar-se em 2012, entre estes o de Diretor Associado e de Diretor da Faculdade de Educação da UNICAMP por oito anos. Fez Livre-Docência e concurso de Professor Titular na área de História da Educação. Recebeu o Prêmio de Reconhecimento Acadêmico "Zeferino Vaz" por destaque em suas atividades de Docência e Pesquisa. Como pesquisador está vinculado ao Grupo de Pesquisa HISTEDBR". De 2012 até a presente data mantém-se como Professor Colaborador da UNICAMP. Tem livros e dezenas de artigos publicados, destaca-se aqui aqueles que se relacionam à entrevista: Movimento Estudantil - A UNE na resistência ao Golpe de 64 (1986), Com o Golpe de 2016, para onde Caminhará a Educação? (2017), A Conjuntura Educacional Atual: para onde Caminha a Educação? (2016), Da Conferência Nacional de Educação - 2010 ao Plano Nacional de Educação - 2011/20 (2011), Sala de Aula: Intervenção no Real (2011), 0 Manifesto dos Educadores (1959) à Luz da História (2007), 0 Compromisso Ético e Político do Educador e a Construção da Autonomia da Escola (2000), Há um Pretexto: 0 Manifesto Completa 150 anos (1999), Crise! Que Crise? (1996), A politecnia no Ensino Médio (1991). 


\section{Sobre o entrevistador:}

Antônio Carlos Maciel, graduado em Filosofia (UFAM) e Pedagogia (UFAM), Especialista em Inovação Tecnológica (ISAE/FVG), Mestre em Educação (UFAM), Doutor em Ciências Socioambientais (NAEA/UFPA), é professor titular da Universidade Federal de Rondônia, onde leciona, em Cursos de Graduação e Pós-Graduação, Metodologia da Pesquisa em Ciências Sociais e Metodologia da Pesquisa em Educação. No Doutorado em Educação na Amazônia, ministra, com outros colegas, a disciplina Problemas Educacionais da Região Amazônica e a temática Trabalho e Educação. Tem vários livros publicados com outros colegas e mais de duas dezenas de artigos, entre os quais Projeto Burareiro de Educação Integral: Original (2016), Currículo e Metodologia da Educação Integral Politécnica (2016), Gestão da Educação Integral Politécnica (2013), Educação Integral Politécnica: da Teoria à Prática (2017), Marx e a Politecnia: ou, do Princípio Educativo ao Princípio Pedagógico (2018), 0 Conceito de Educação Integral e as Possibilidades da Educação Integral Politécnica em Manaus (2019), A Revolução Francesa e a Educação Integral no Brasil: da concepção ao conceito (2020).

ACM: Professor Sanfelice, sua formação escolar remonta aos anos 1950 e 1960, no estado de São Paulo. Que diferenças você pode apontar entre a formação pela escola daquela época e de hoje?

JLS: De fato, eu iniciei minha escolaridade nos anos cinquenta do século passado. Com o auxílio de uma tia professora de Grupo Escolar, meus pais conseguiram a vaga para que eu fosse matriculado lá. Só isso já revela muita coisa. 0 Grupo Escolar estatal e gratuito era uma instituição rara e disputadissima em cidades do interior do Estado de São Paulo. Atendia a um público razoavelmente selecionado e costumava ser a principal instituição escolar das cidades nas quais era implantado para atender a educação inicial de crianças. A História da Educação mostra que o Grupo Escolar vinha do projeto civilizatório do início da República no Brasil. Como já se consagrou na historiografia, eram os Templos de Civilização. Em geral, foram concebidos desde um projeto arquitetônico até faraônico para $\circ$ início do século XX e com propostas pedagógicas que mesclavam a pedagogia tradicional e a Escola Nova. Várias cidades brasileiras conservam, como patrimônio histórico, os seus prédios dos Grupos Escolares. Eu mesmo lamentei muito quando na minha cidade natal (São José do Rio Preto - SP) se demoliu, para uma nova acomodação da organização urbana local, o prédio do Grupo Escolar "Cardeal Leme", no qual eu havia estudado. 0 prédio era um ícone na memória de tantos que por lá passaram. Constituía-se em verdadeira simbologia na mente social.

Tudo bem, mas por quê? Porque ao longo dos anos seus ex-alunos tornaram-se médicos, engenheiros, jornalistas, professores, advogados, politicos e tantos outros profissionais 
liberais da cidade. Em geral, tal acontecimento não foi decorrente da possível ascensão social dos indivíduos, mas uma confirmação reprodutiva da origem social de suas famílias. Então, o Grupo Escolar era, de alguma forma, elitizado, tanto é que alguns poucos alunos precisavam ser assistidos por uma Caixa Escolar que os auxiliava, por exemplo, dando-lhes sopa na hora da merenda, providenciando alguns materiais escolares ou uniformes. Eram os pobres do "Grupo". Havia, no paralelo, a oferta de escolas privadas para parte das elites, principalmente para o público feminino economicamente favorecido e escolas de caridade. Boa parte dos sujeitos em idade escolar não frequentava escola nenhuma. Sintetizando: o Grupo Escolar era uma construção apropriada para as suas atividades, com espaços adequados para as diferentes atividades, com número limitado de alunos por classe, com profissionais permanentes e formados especialmente pelos Cursos Normais e especializações para aquele modelo pedagógico. 0 sexo feminino predominava na docência e a maioria das professoras eram "verdadeiras damas" admiradas e respeitadas pela sociedade. Apesar dos problemas que obviamente existiam, o Grupo Escolar tinha sucesso quanto à aprendizagem de boa parte dos seus alunos. Da caligrafia, do desenho à tabuada, ninguém escapava. A leitura e a escrita eram praticamente garantidas aos sobreviventes, após os quatro anos de Grupo. Havia um quinto ano de reforço para alguns que não tinham sucesso imediato na ascensão ao Ginásio estatal, após Exame de Seleção, um verdadeiro vestibular precoce na época. Os “Grupos Escolares” projetaram no imaginário social um ensino de qualidade mascarando a realidade da elitização, portanto da não inclusão da maioria das crianças em suas dependências. Foram úteis, sim, para um público específico mais próximo, pela sua origem social, da cultura escolar. Em seu favor, o caráter estatal, gratuito e oficialmente laico, apesar de contemplar o ensino religioso.

Comparações com a escola estatal de hoje implicam em atentar para contextos históricos muito diversos e algo a ser feito de modo meticuloso e não genérico. Entretanto, para atender à indagação, ouso uma brevíssima formulação. Naqueles tempos o Grupo Escolar formava e/ou instrumentalizava os indivíduos com técnicas, habilidades e certa cultura fundamental e genérica, mais ou menos homogeneizadas por determinados segmentos sociais que as exigiam e se reconheciam nelas. Daí a imagem fictícia de qualidade, ou qualidade real para poucos, sem a percepção de que a quantidade de Grupos era infinitamente aquém da possível demanda. Hoje, a diversidade da escola estatal em todas as suas dimensões - esta é uma das suas qualidades atuais - não viabiliza aquela representação anterior de qualidade. Não se pode esquecer que a qualidade depende também da quantidade. Projeta-se a ideia persistente da perda daquela qualidade, da queda de nível e outras demais mazelas, num saudosismo que não reconhece os ganhos quantitativos que são o ponto de partida para uma nova conceituação de qualidade. Temos que fazer outra leitura dessa dimensão indutiva utilizada para o descrédito da escola estatal, que decreta a sua falência, e reivindica como solução sua privatização. As realidades de ontem e hoje são muito diferentes. 
ACM: É consenso entre os educadores, que a escola existente no Brasil, a partir da Lei 5.692/71, comparativamente, com a escola dos anos 1950 e 1960, é uma tragédia. Darcy Ribeiro (1984) chega a chamá-la de "calamidade". Por aproximadamente trinta anos (com raríssimas exceções estaduais, CIEPs e CEUs, por exemplo), a escola foi reduzida a salas de aula superlotadas, pequeníssimos espaços para a direção, orientação e supervisão, minúscula biblioteca e, quando muito, uma quadra de esportes; relações autoritárias de trabalho e política salarial cada vez mais degradantes, associando-se a isto uma precária formação de professores (técnica e política). Exceções à regra, em termos de formação, que males essa escola trouxe à juventude brasileira e ao próprio sistema escolar público?

JLS: Não concordo com a leitura interpretativa contida na pergunta, por conta do ponto de onde eu parti na questão anterior. 0 s anos '50 e '60 do século XX assinalam certa expansão quantitativa de escolas estatais. A ampliação, nas décadas seguintes, será cada vez maior e com momentos de aceleração ou desaceleração. Não tínhamos escolas em tal quantidade antes e a caminhada continuará até nos aproximarmos da universalização, mais recentemente, pelo menos do ensino fundamental. Então não havia uma rede de escolas a serem recuperadas ou avaliadas quanto à sua qualidade. Simplesmente tínhamos poucas escolas, como aquele Grupo Escolar em que estudei, herdadas do projeto republicano, já esgarçado ao longo da República Velha, comprometido após 1930, moldado pelo nacional desenvolvimentismo dos anos '50 e '60 e submetido à ditadura do Movimento Civil-Militar de 1964, quando então se aprova a Lei 5692/71, modificando a LDB 4024/61. Deve-se buscar a leitura da história da construção da escola estatal nas diferentes conjunturas do modo de produção capitalista tupiniquim. Prefiro, então, outra afirmação de Darcy Ribeiro que aponta: "A crise da educação no Brasil não é uma crise: é um projeto".

Eu mesmo mudei, nos anos '80, a denominação de um curso que ministrava sob o título "A recuperação da escola pública brasileira" para "A construção da escola pública brasileira". É sempre uma construção e não uma desconstrução, se entendermos como o Estado burguês administra e ministra a educação para atender necessidades objetivas do capital e do Estado, visando também mediar àquelas pressões que as classes trabalhadoras fazem desejando acessarem a educação formal, nem sempre em concordância com as expectativas expansionistas do capital e do próprio Estado. A compreensão crítica e revolucionária da realidade não pode escorregar para um denuncismo daquilo que a educação poderia ter sido e não foi. É como ficar achando que a burguesia e o Estado burguês pudessem ter sido, aqui nas nossas especificidades de uma sociedade colonizada, subalterna e dependente, outra coisa além daquilo que realmente foram e são. Não tem como. Então partilho de um conformismo? Não e não. Buscando conhecer a realidade e as determinações do projeto educacional e escolar burguês, aposto na utopia. Como converter a escola estatal burguesa em escola de interesse e serviço realmente públicos? $\mathrm{E}$, evidentemente, sei que isso 
implica em um projeto maior e que luta por construir outro tipo de sociedade. Mas, concluindo: a Lei 5692/71 veio alterar a LDB 4024/61.

A nossa primeira LDB tramitou por longos anos no Poder Legislativo, emperrada em discussões que representavam diferentes interesses de classes e grupos sociais. Concomitantemente, desenhou-se o denominado nacional desenvolvimentismo e cujo desfecho culminou no Movimento reacionário e golpista de 1964. Os interesses educacionais do Estado autoritário civil-militar e do capital local, associado ao imperialismo, logo se materializaram na reforma universitária de 1968 com a Lei 5540. Para responder à nova ordenação econômica pretendida pelos golpistas, fez-se necessário também alterar a LDB com a edição da Lei 5692/71. 0 Brasil havia ingressado em um processo acelerado de urbanização e de alguma industrialização com a participação de interesses multinacionais. A população mais urbana e a ampliação das classes médias também demandavam oportunidades educacionais, tendo em vista a sua possível participação em maiores e melhores atividades profissionais e empregatícias. A legislação vem como resposta administrativa ao novo cenário e, claro, segundo a ótica do capital e nos limites que ele entende possível implementar no campo da educação. Esperar mais do que isso se torna ingenuidade. Por exemplo, implementou-se a compulsoriedade da profissionalização no ensino médio, sem que ela ocorresse de fato. 0s alunos concluintes eram certificados, mas eles não tinham nenhum preparo para o exercício real da profissão, uma vez que as escolas não se adaptaram material e pedagogicamente às exigências legais. Mas certificavam sem nenhum constrangimento. Era uma forma de satisfazer à demanda da população por maior escolaridade, acima das necessidades do capital, com um engodo quanto à profissionalização. Por outro lado, criava-se um bom exército de mãode-obra de reserva, com alguma escolaridade e que poderia ser rapidamente treinável para possiviveis exigências do mercado.

A Escola estatal básica continuou sua expansão, inclusive ampliando a obrigatoriedade dos anos de escolaridade, repercutindo na liberação de mais mão-de-obra feminina para o mercado de trabalho e construindo depósitos de crianças pobres, sob o rótulo de Escola, pelos bairros e periferias das cidades. Claro que os profissionais dessas escolas também foram sendo desqualificados, seja pela formação precária e aligeirada ou pelo imenso desafio que se thes colocou e sem suporte efetivo. A teoria do Capital Humano e o tecnicismo foram as referências teóricas inspiradoras para as novas práticas e políticas educacionais. Nada disso, entretanto, pode surpreender e menos ainda se trata de fazer uma leitura conspiracionista da história. A burguesia e o Estado burguês não conspiram contra o resto da sociedade, tanto quanto os padres jesuítas não se consideravam verdadeiros exterminadores das sociedades indígenas quando da colonização. Pelo contrário, se apresentaram como os salvadores. Eles, os dominantes e hegemônicos, simplesmente desenvolvem o próprio projeto histórico, dentro dos seus limites de interesses e visão de mundo, como se fosse um projeto adequado e satisfatório para todos. 
Mas, não participo da ideia deles e não me furto a dizer que a educação oferecida por eles às novas gerações, por meio da atuação da Escola estatal, tem sempre um grande poder de controle e de alienação sobre as massas crescentes que a frequentam. Posso até dizer que a rede escolar estatal, com suas reconhecidas carências, segundo os seus críticos, funciona adequadamente e bem para os propósitos reais aos quais se destina, e não para os propósitos proclamados. Um exemplo seminal? Da Ditadura civil-militar de 1964 em diante vem diminuindo o espaço da formação no campo das Humanidades, em todos os níveis do ensino. Hoje, já há quem negue que a Ditadura foi uma realidade cruel ou mesmo que tenha existido. A mesma pessoa com tal opinião pode ser um advogado, um jornalista, um médico ou um professor. Falta-lhe formação cidadã-democrática e revela profundo desconhecimento histórico. Tal postura é um grande prejuízo formativo para a coletividade, mas é muito eficiente aos poderes instalados.

ACM: Apesar disso, essa escola permitiu acesso à Educação Básica, como jamais fora presenciado no Brasil. No final dos anos 1990, inclusive, com base nas estatísticas educacionais, o MEC apresentava dados, os quais demonstravam que, enfim, o Ensino Fundamental fora universalizado. Assim, em termos de escola pública lou estatal, como queira), temos uma escola que se move, dos anos 1930 aos anos 1960, pela contradição qualidade versus exclusão (exclusão da faixa-etária em idade escolar); dos anos 1970 ao início dos anos 2000, a escola se move pela contradição acesso versus desqualificação do ensino. Ficando à vontade para discordar dessa afirmação, como você analisa esses dois períodos educacionais?

JLS: Acredito que as respostas anteriores já adiantaram razoavelmente a temática objetivada agora, ou seja, a Escola estatal de qualidade versus a exclusão etária dos alunos em idade escolar, típica dos anos '30 a '60, e a ampliação do acesso versus a sua desqualificação até meados dos anos '90. Primeiro, não há como desconsiderar o óbvio e já dito: a Escola estatal (de qualidade?), no início de oferta reduzida e excludente, foi significativamente ampliando as possibilidades de acesso a ela, com ofertas quantitativas crescentes de novas unidades e ampliação e diferenciação do público frequentador. É um dado não controverso. Uma sociedade em processo de modernização necessitava disso e o Planejamento estatal, para a expansão, considerou o barateamento de custos que implicavam, para citar apenas um exemplo, em construir prédios mais simples e em locais mais baratos e periféricos. Este tipo de precarização tornou-se um contínuo até chegarmos às denominadas Escolas de Lata, carrocerias de caminhões convertidas em salas de aula nas periferias, porque a população quase sempre exige, por entender corretamente ser um direito seu, mais escolas do que o programado pelo Estado. 
As alterações legais também pressionaram a expansão, mas os recursos necessários não foram nunca provisionados de modo satisfatório. Constituiu-se outro tipo de escola com um público diferenciado e diverso, com currículos aligeirados, aumento de turnos reduzidos, professores cada vez mais precarizados na sua formação e com grande descaso pela configuração da carreira docente. Se "o povo" foi conquistando a sua oportunidade escolar, o Estado burguês não the providenciou uma escola como aquela existente antes que "o povo" entrasse na Instituição. Houve exceções com tentativas pontuais e muito passageiras de se construir algo melhor e diferenciado da lógica dominante. Não foram muito longe e acabaram absorvidas ou até mesmo censuradas.

Segundo, havia antes uma escola de qualidade? 0 que exatamente se considera qualidade? Bem, como não estamos nos referindo à realidade de nenhuma sociedade revolucionada, e sim a uma sociedade capitalista de hegemonia da burguesia e do Estado burguês, com todas as especificidades da realidade brasileira, acabamos também mencionando uma escola resultante das determinações desse tipo de sociedade. Logo, acatando a afirmação de que a escola elitista era portadora de qualidade, reconhecemos a escola da realidade capitalista burguesa como de qualidade, mesmo que ela não fosse diretamente voltada aos filhos da burguesia e sim para as classes médias, por exemplo, onde se recrutava burocratas, administradores, intelectuais, profissionais liberais, políticos, militares, padres etc. Algum problema quanto a tal reconhecimento? Não necessariamente, desde que concordemos que a burguesia fez avanços excepcionais no seu processo civilizatório revolucionário para a superação do feudalismo. Um deles, sem dúvida, foi retirar a educação pública do monopólio da lgreja. Outro exemplo é o investimento nas ciências para acelerar o desenvolvimento das forças produtivas. São qualidades do papel histórico da burguesia que muito provavelmente não poderão ser ignoradas na construção de uma sociedade superior qualitativamente à atual. Mas os objetivos últimos da educação e da ciência terão que ser redefinidos. Daí a questão se coloca: É a escola de qualidade do passado que estamos querendo resgatar? É aquela qualidade que nos inspira na nossa utopia? É preciso verificar que quando problemas extraeducacionais exigiram mais escolas, o Estado burguês não "democratizou" a escola originária de qualidade, segundo a sua perspectiva. 0 crescimento urbano, o aumento populacional, a favelização, a ampliação da pobreza, enfim, a reprodução das classes potencialmente trabalhadoras necessita, na ótica burguesa, de procedimentos de gerenciamento para que não haja convulsões sociais profundas.

A escola desqualificada é uma resposta "elegante" que inclui, excluindo. Aquela escola de qualidade do passado não foi pensada para ser levada a um público de periferia que não tem nada em comum com os antigos alunos do Grupo Escolar já referido. São pessoas de outra origem social e portadoras de culturas que nunca foram referenciadas nas escolas de "boa qualidade". Como temos muitos e diferentes tipos de periferias, numa sociedade de profundas desigualdades, a Escola estatal "democratizada" não sabe nem o quê e como dialogar 
com o seu novo e múltiplo público. É possível que essa população não esteja interessada em apreender aquilo que os Parâmetros Curriculares ou o Banco Mundial insistem em impor. A leitura do "Manifesto dos Pioneiros da Educação Nova" de 1932 dá muitos elementos para se perceber como um grupo de intelectuais liberais avaliava o desenvolvimento da educação no Brasil, até então, para proporem o que desejavam pela frente.

É mais interessante ainda acrescentar o "Manifesto dos Educadores: mais uma vez convocados" de 1959 que mostrava, basicamente no mesmo grupo de intelectuais, as frustações pelo não realizado, e novamente a reafirmação do que havia por se fazer em educação. A própria fração burguesa mais avançada, vinculada ao processo de industrialização, manifestou pela voz dos intelectuais dos Manifestos, a avaliação qualitativa da escola republicana até 1930 e do seu desenvolvimento até os anos '60. Não partilho da análise liberal porque se assim o fizer acabo por me convencer de que os dois Manifestos ainda devem nos servir de guia ou inspiração. Teríamos que fazer um novo Manifesto ainda dentro da lógica liberale Reconheço, sim, a expressão histórica daquelas ideias que me auxiliam a compreender o passado, mas não como fonte de inspiração. A pergunta agora é: 0 que temos que fazer com a escola fundamental estatal universalizada e partindo das condições em que ela se encontra? Este problema e desafio são nossos e a resposta não virá do Estado.

ACM: Se as políticas educacionais são o meio pelo qual as elites determinam a condição pauperizada da escola pública, por que há tantos pesquisadores, inclusive, socialistas (marxistas, anarquistas, trotskista, etc.), que insistem em tomá-las como referência de suas análises, no sentido de cobrar do Estado que cumpram as leis educacionais? Mas, se as leis, no Estado burguês são aprovadas exatamente para fazer de conta que o Estado visa ao bem comum, não seria uma infantilidade cobrar desse Estado o cumprimento de suas promessas legais?

JLS: Penso que quando as esquerdas cobram do Estado burguês que produza uma educação qualificada para as classes trabalhadoras, não está endossando o conceito de qualidade que a burguesia incorpora, por exemplo, de simplesmente formar homens e mulheres empregáveis, homens e mulheres dóceis em relação ao modo de produção capitalista e que se matam no mercado de trabalho para sobreviverem alienando o seu trabalho ao capital. Seria como estar clamando por algo assim: queremos de fato ser empregáveis com a boa preparação que vocês burgueses podem nos oferecer por meio das escolas estatais. Caso isso ocorra, claro está que é um equívoco. Insistir no cumprimento da legislação, fruto em geral do pensamento liberal, é uma forma de ataque e defesa. Ruim com a lei, pior sem ela. A crítica e a cobrança têm que ter um sentido, primeiro, de denúncia. Aquela educação praticada pelo Estado burguês não convém às demais classes sociais, mas cobrar pelo proclamado e não realizado, é uma forma de enfrentamento no quadro mais geral da luta de classes. 
Em segundo lugar, é uma postura de tomada de consciência do processo de embate. É preciso difundir que a burguesia não pode agir coerentemente com o que proclama. É necessário conhecer e desmascarar o adversário. Do mesmo modo que os trabalhadores lutam por melhores salários, pugnam também por uma educação melhor, mas sabem que não são estes os fins últimos da contraposição que se está travando. Se sabemos que a sociedade capitalista é inconsertável, temos que saber que a educação estatal burguesa também o é. Mas, trava-se a peleja por uma educação universal de qualidade, gratuita, laica, de comprometimento social, igual e integral conceituando cada um destes princípios numa perspectiva que tem que ser revolucionária, senão é inócua. Se a classe trabalhadora visa a apropriar-se socialmente dos meios de produção e não os destruir, o mesmo deve acontecer com a escola estatal. Ela não é sustentada pelos recursos públicos resultantes da cobrança dos impostos recolhidos junto à população? Existe, nas condições de hoje, outro "sistema" educacional a ser disputado e que a classe trabalhadora possa frequentar? Então, temos que construir nossa proposta de políticas educacionais ocupando todos os espaços possíveis para resistir e avançar. É uma ocupação por incorporação e superação, e não por exclusão, negação e destruição simples do que já existe.

Não se está defendendo um retorno à barbárie. É um procedimento inspirado num pensamento que se apropria da lógica-dialética da história e não da lógica formal que privilegia a não contradição. A escola estatal burguesa, espaço de embates, tem que ser convertida em uma escola dos interesses das classes trabalhadoras e não permanecer como uma escola que a burguesia thes impõe de acordo com sua ótica de classe dominante e hegemônica. Prestemos atenção nos organismos e agências mundiais que regem a educação nos países globalizados e periféricos, privilegiando a ótica do capital. Não abrem mão do controle, do financiamento, do estabelecimento de metas, das medidas de avaliação, da imposição de currículos e conteúdos de aprendizagem. Resulta tudo numa escola que consideramos desqualificada, mas é a escola que a burguesia não abre mão dela, a não ser na perspectiva de que seja privatizada. Daí incorporarmos também a bandeira de luta contra a privatização do ensino em todos os seus níveis. Os projetos das políticas educacionais do Estado burguês não visam a garantir a educação como um direito. Nós, sim. Não podemos ter a ilusão de que a burguesia e a escola burguesa se comportem como se não fossem o que de fato são e trabalhando para a construção de uma história que thes convêm. Assim emergem as contradições que é o fulcro do conflito onde as classes trabalhadoras e as esquerdas, defensoras de uma educação emancipatória e para uma sociedade que ainda não existe, devem atuar. É a utopia que nos mobiliza e nos conduz.

ACM: Uma das facetas messiânicas de que Estado liberal possa vir a cumprir um papel de equalização social e, talvez, um equívoco do que se convencionou chamar de 
esquerda no Brasil, reside na crença nos governos socialdemocratas, PSDB e PT, os quais, no final das contas, com maior ou menor intensidade, terminaram por implementar políticas neoliberais determinadas pelos organismos internacionais. Se os governos socialdemocratas sucumbiram aos atrativos neoliberais, que papel cabe à esquerda, hoje, no Brasil?

JLS: Deixando claro, desde o início: eu não considero que a Social Democracia seja a alternativa de superação do modo de produção capitalista e da realidade sistêmica da sua prática de exploração do trabalho da maioria dos homens e mulheres mundo afora. $A$ Social Democracia praticada em alguns países no transcorrer do século XX (França, Holanda, Espanha, Suécia e Áustria) tem, apesar de tudo, suas características de encantamento, pois aponta para uma possível correção de extremos praticados sob a inspiração do pensamento econômico político liberal e neoliberal. Aceitando os principais fundamentos da ordem burguesa do capital, promove reformas parciais, utilizando-se da política de intervenções econômicas e sociais. É rotulada por muitos como uma postura de centro-esquerda por valorizar princípios de igualdade e liberdade (liberdades civis, direitos de propriedade e democracia representativa). A construção do Estado de Bem-Estar social é uma decorrência da concepção Social Democrata. 0 Estado é o regulador da vida social e econômica do conjunto da sociedade. Deve estimular, do ponto de vista econômico, o aumento da demanda interna, ampliando a renda do trabalhador por vários mecanismos de iniciativa do Estado, um provedor de serviços públicos abrangentes e de qualidade, como o pleno emprego e melhores salários, salário mínimo, jornada de trabalho, seguridade social, aposentadoria etc. 0 Estado é também o gerenciador dos processos de negociação junto aos sindicatos e deve investir em infraestrutura de grande porte.

Para liberais e neoliberais, o cerne da Social Democracia pode incomodar parte dos seus princípios no que diz respeito ao papel do Estado que, para muitos deles, deve ser mínimo e, também, no que diz respeito ao livre mercado. Para as esquerdas revolucionárias, penso eu, a Social Democracia está aquém do projeto de revolução de uma sociedade superior à capitalista. Como já dito, o modo de produção capitalista é inconsertável e a Social Democracia pretende apenas torná-lo menos ruim. Seria estrategicamente defensável como passagem para a sociedade igualitária? A história tem dito que não. Como não é uma concepção contestadora da essência do capitalismo, ou seja, para a Social Democracia, a exploração do trabalho pelo capital, torna-se conjunturalmente conveniente para disfarçar o cerne do que deve ser quebrado, exatamente a exploração do trabalho pelo capital. De forma contínua, a Social Democracia vem sucumbindo à lógica liberal e neoliberal, inclusive pela retomada da direita e da extrema direita mundial que protagonizam, na globalização, o retorno à barbárie sem fronteiras. Registre-se, ainda, que a atual revolução tecnológica e do mundo do trabalho são também fatores cruciais e objetivos para que a Social Democracia não se sustente. 
ACM: Afinal, o que é esquerda hoje no Brasil?

JLS: A pergunta anterior concluía indagando: "Que papel cabe à esquerda hoje no Brasil? E, agora, a pergunta é: 0 que é a esquerda hoje no Brasil? Muito difíil responder com objetividade, pois, no momento em que vivemos no Brasil, milhões de pessoas identificam a esquerda com tudo o que pode existir de pior na sociedade. Os adjetivos mais desqualificadores do vocabulário são atribuidos às esquerdas. E, como é sabido, construiu-se um ódio às esquerdas, colocando-se num mesmo balaio "gatos de todas as espécies", uma postura quase genérica e que foi importantíssima para levar o presidente Bolsonaro e as forças truculentas de direita à vitória eleitoral. Utilizou-se de um genérico e impreciso termo, os comunistas, para anatemizar todos os adversários. Vou tentar, apesar de tudo, algumas considerações.

De uma forma simplificada e genérica, podemos dizer que no espectro politico mundial a esquerda incorpora todos os movimentos que de alguma forma são críticos às relações sociais geradas pelo modo de produção capitalista e a alguns ou todos dos seus fundamentos. Posturas progressistas, reformistas, anarquistas, socialistas e comunistas de muitas configurações são consideradas as constitutivas das esquerdas. Nem sempre tais posturas se autodenominam com essa nomenclatura, mas na luta ideológica acabam assim identificadas, por exemplo, pelo discurso reacionário liberal, neoliberal ou ultraconservador (fundamentalistas, adeptos dos regimes totalitários e ditatoriais, entre outros). Entretanto, boa parte dessas esquerdas, como progressistas e reformistas, convivem com o status-quo que desejam amenizar e, quase sempre, vamos dizer assim, por um processo de osmose integram-se ou são absorvidas por ele conjunturalmente. Quando as conjunturas se alteram, vem a derrota dos possiveis avanços obtidos.

Então, ○ que falta a essas esquerdas? Falta exatamente $\circ$ projeto utópico revolucionário que é o de destruição e superação das relaç̃̃es de exploração do capital sobre o trabalho e com ações politicas consequentes em prol da meta visada. 0 papel da esquerda é o de trabalhar didática e pedagogicamente na exposição do seu ideário e de difundi-lo universalmente na luta contra os preconceitos e ataques que sofre dos seus adversários. É fundamental demonstrar que há outro projeto de sociedade e conseguir explicitar as diferenças entre eles. Também é necessário trabalhar junto e com as bases sociais de resistência que necessitam de alternativas para as suas emancipações. Formar quadros de militância política é fundamental, tanto quanto arregimentar adeptos da causa em pauta e constituir-se em vigilante/denunciante dos artificios que a ideologia burguesa se utiliza, somados à capacidade repressiva do Estado, e que visam o desmonte das organizações das classes trabalhadoras. De forma orgânica, constituir partidos expressivos dessas classes (não estou defendendo a revolução pela disputa somente politica) e que compreendam a 
necessidade da luta em nível econômico, político, ideológico e para além da lógica do capital. Sem resistência, ideário e práticas revolucionárias não há esquerda.

ACM: Professor, como você analisa as posições, segundo as quais as relações promíscuas entre os socialdemocratas e os liberais construíram as condições para a ascensão da extrema direita ao poder?

JLS: Imagino dar aqui uma resposta mais breve. Primeiro, considero que a extrema direita nunca morreu. Perdeu espaços e eleições exatamente por conta das alianças entre socialdemocratas e liberais em conjunturas específicas de rearranjos da economia capitalista. Foram conjunturas em que o modo de produção capitalista se reestruturou e expandiu mundialmente após as duas grandes Guerras. A socialdemocracia foi um antídoto que freou as esquerdas que se inspiravam na experiência da ex-União Soviética, e posteriormente nas Revoluções chinesa e cubana. Com os pactos estabelecidos, o capitalismo passou a ser apresentado como algo mais palatável. As dificuldades e eventuais equívocos internos da exUnião Soviética, no transcorrer da Guerra Fria, criaram muitos embaraços para as esquerdas internacionais em suas respectivas realidades nacionais. Com o desmoronamento do Muro de Berlim, em 1989, advogou-se, no mundo capitalista, a tese da morte do socialismo real e das utopias socialistas e comunistas. Parte significativa de expressivos militantes das esquerdas se desbaratou face aos novos acontecimentos. Houve uma ruína teórica e moral que se impôs para parte das esquerdas e que não tem facilitado reencontrar caminhos. A aliança da socialdemocracia com os liberais, por sua vez, parecia ser a solução para a história, tanto é que muitos ideólogos passaram a advogar o Fim da História. Com a queda do Muro de Berlim e o fim da Guerra Fria, o capitalismo deglutível era apresentado como o ápice possível do desenvolvimento da humanidade. Se assim não fosse, restava caminhar para a barbárie.

A extrema direita sub-reptícia e ativa voltou a ocupar espaços onde a socialdemocracia foi sendo dispensada de servir como amortecedora dos impactos da exploração capitalista. Sem a Guerra Fria e os riscos proclamados do socialismo e comunismo, o capitalismo podia voltar a mostrar suas garras não usando luvas. A globalização econômica, a mundialização das teses e da ideologia neoliberais, a monstruosa revolução tecnológica que alterou radicalmente o mundo da produção e das relações do trabalho, tudo junto somado e ao mesmo tempo, resultou numa espécie de descrédito quanto à possibilidade de uma sociedade esclarecida pelas luzes da racionalidade. Ainda que as desigualdades tenham uma natureza histórica no país, as hordas de desempregados e milhões de miseráveis passaram a perambular por todos os cantos. As desigualdades sociais radicais cresceram dia a dia. As lutas das classes trabalhadoras se arrefeceram. 
0 pensamento pós-moderno, bastante utilitário à nova (des)ordem, condena os sujeitos à sua própria individualidade: cada um é único e exclusivamente o responsável pela própria história e condenado à sua verdade subjetiva. A extrema direita consolida-se no ambiente da aparente balburdia onde liberais e socialdemocratas não conseguem responder aos desafios dos novos tempos. Como ilhas salvadoras são extremamente conservadores, apregoam extremismos, defendem posturas nacionalistas fechadas, preconceituosas contra indivíduos e culturas, elitistas e exclusivistas. Costumam defender regimes políticos totalitários e, não raro, baseados em fundamentalismos. 0 crescimento político dos partidos de extrema direita mostra que ainda é possivel encantar sujeitos com propostas oriundas da prémodernidade burguesa e que não se orientam por um olhar ao futuro, mas sim para o passado. Nessa questão, seria fundamental analisar o papel das mídias e das redes sociais no suporte que dão ao retorno da extrema direita. Também valeria muito concretizar a análise do período mais recente da história do Brasil: como as alianças dos liberais com as tênues defesas e práticas da socialdemocracia após 1985 resultaram, trinta anos depois, na avalanche de extrema direita do governo do golpista Temer e na eleição do "Mito" Bolsonaro? Contaram com a participação dos liberais? E as esquerdas como se comportaram e estão se posicionando?

ACM: Entre os vários espaços no interior do Estado brasileiro, há o educacional. 0 que se deveria esperar dos Partidos de esquerda na área da educação?

JLS: 0 que se esperar dos partidos políticos de esquerda na área da educação? Bem, consideremos que a burguesia fez a sua revolução baseada em lemas como Liberdade, lgualdade e Fraternidade. Ao longo da história ela vem demonstrando ser incapaz de construir qualquer sociedade que tenha tais características. Muito pior, vai à contramão do seu lema revolucionário. Então, sem nenhum pudor, este lema tem que ser empunhado pelas esquerdas para que um ideal humanamente intrínseco se concretize. Mas, é fundamental reconceituar Liberdade, lgualdade e Fraternidade, uma vez que a concepção originária liberal não é a mesma das esquerdas revolucionárias que entendem que nenhuma daquelas três dimensões pode se materializar numa sociedade de modo de produção capitalista. A bandeira reconceituada muda de mãos e não há como a burguesia voltar a desejá-la, a não ser como uma grande farsa. Por exemplo, estamos em plena crise do Covid-19 e podemos assistir às manifestações da burguesia lagentes do sistema financeiro, grandes empresários e o presidente Bolsonaro, laranja do grande capital e servo fiel do imperialismo norte-americano) sobre o que pensam da classe trabalhadora, dos trabalhadores informais, dos desempregados e demais segmentos subalternos. É racionalmente inaceitável o imenso desprezo que manifestam às vidas dos homens e mulheres trabalhadores e privilegiando somente a obtenção de lucros em plena pandemia. Não conseguem nem escamotear os desejos de que realmente são portadores. 
Que morram milhares de pobres e velhos, pois restarão milhões a serem explorados. E, em plena crise, o Parlamento vem devastando os direitos dos trabalhadores. 0 chamado socorro aos bancos é vergonhoso. Mas, voltemos ao foco da pergunta.

A burguesia também foi a responsável pela criação da Escola estatal. Atribuiu ao Estado, seu representante fiel, o papel de se tornar o educador das massas e com o uso dos recursos públicos (sim, cobrando impostos da população). 0 primeiro grande avanço foi a laicização da educação no âmbito estatal, retirando do controle da lgreja a função de formar os sujeitos necessários ao mundo do trabalho na ordenação do modo de produção capitalista. 0 segundo passo adiante foi a busca de se criar sistemas nacionais de educação e que, por consequência, implicaram em medidas de universalização. Isto posto, torna-se necessária uma grande incursão pela realidade da escola estatal, fruto do projeto burguês, para captar a sua verdadeira identidade histórica. Não tenho como fazer isso aqui e, portanto, vou pecar pela simplificação. A escola estatal laica, gratuita, universal e de qualidade é, em síntese, a bandeira no campo educacional. Espera-se que partidos de esquerda não façam concessões quanto a isso. A laicidade é um exemplo do engodo, pois não arrefece nunca o assédio para impor o ensino religioso nos currículos das escolas estatais. A gratuidade vem sendo combatida fortemente pelo imenso tom do privatismo. A universalização, ainda modesta quando considerado todos os níveis de ensino, é centrada na diferenciação qualitativa para os públicos alvos a serem captados. A escola estatal burguesa não visa, de fato, ser igual para todos. Então, de novo, escola estatal laica, gratuita, universal e de qualidade não são princípios a serem abandonados, mas nas mãos dos partidos de esquerda e, também, reconceituados, devem constituir-se em propósitos efetivos de conquistas e realizações.

No espaço educacional estatal são inúmeras as frentes de lutas a serem travadas. Vou nomear apenas algumas e sem nenhuma ordem de relevância: as garantias constitucionais de investimento na educação, hoje, mais do que nunca, vilipendiadas pelas reformas impostas desde o governo do usurpador presidente Temer; o resgate do Plano Nacional de Educação de 2014 a 2024 que foi totalmente abandonado; a política nacional de formação dos professores; a valorização da carreira docente e a garantia do piso salarial; a liberdade de cátedra e o enfrentamento com o Movimento Escola sem Partido; o embate com as posturas anticientíficas embutidas dentro do próprio MEC; um posicionamento sobre as políticas de cotas; a garantia de acesso a todos os níveis de escolaridade com o sustento de políticas de permanência dos alunos ao longo dos anos; a construção da gestão escolar democrática e participativa; o combate à misoginia, à homofobia, ao bullyng, ao racismo e machismo nos ambientes escolares e fora deles; a explicitação e a defesa contundente de uma educação omnilateral que se oponha frontalmente à formação unilateral imposta na escola estatal burguesa para a formação do trabalhador alienado. As discussões sobre currículos são fundamentais. Enfim, a lista de possíveis sugestões é imensa e valeria fazer uma consulta aos programas dos partidos considerados de esquerda para se constatar ou 
não essas e outras preocupações em seus tópicos. Na prática, é preciso ocupar os espaços onde os embates se travam: nos órgãos de representação estudantil e de docentes, nos Conselhos de Escolas, nos Poderes Legislativos, nas Associações de Pais e nas entidades da área. A arregimentação de forças exige o envolvimento de amplas coletividades. A ideia é salvar a escola estatal burguesa? Não e não. A ideia é educá-la para que se torne de domínio dos interesses públicos das massas (classes trabalhadoras e demais não burgueses). É uma luta continua pela utopia. Aquela utopia que não nos imobiliza contemplativamente, mas nos move para lá. Há um norte.

ACM: As definições do conceito "educação integral" variam de acordo com as concepções político-epistemológicas que as respaldam. Assim, educação de tempo integral é um processo educativo escolar, que prioriza o tempo de permanência do estudante na escola, cuja finalidade, quando muito, é a preparação especializada desse estudante; já educação integral liberal é o processo educativo escolar, que visa ao desenvolvimento das múltiplas capacidades humanas do estudante, preparando-o para a vida na sociedade liberal; enquanto que educação integral politécnica ou emancipatória visa ao mesmo desenvolvimento das múltiplas capacidades humanas, mas formando criticamente o estudante para o exercício transformador das determinações econômicas, políticas e sociais da sociedade capitalista (MACIEL; SILVA; FRUTUOSO, 2019). A modalidade de tempo integral nem deveria ser classificada como educação integral, na medida em que, não raramente, em nada se diferencia do ensino parcial regular. Tendo por base essas definições, não é contraditório que os governos socialdemocratas tenham optado exatamente pela modalidade de tempo integral?

JLS: Se entendo bem a pergunta, comento dois dos seus aspectos. Primeiro, o mais simples, pois ela já estabelece as diferenças entre três possíveis concepções políticoepistemológicas de educação integral, ou seja: educação de tempo integral, educação integral liberal e educação integral politécnica e emancipatória. De acordo. Considero suficiente a distinção anunciada. Em segundo lugar, a estranheza da pergunta se manifesta quanto à escolha dos socialdemocratas por uma educação de tempo integral e não pelas duas outras. Bem, não sei se tal afirmação pode ser generalizada ou se ela se refere a um contexto específico, como por exemplo o da educação brasileira, desde que se considere a presença da socialdemocracia por aqui, em sua união com os liberais, nos governos após 1985. Vou me ater a esta hipótese.

Os estudiosos da educação brasileira, filósofos, historiadores, sociólogos e economistas indicam, desde o governo de Itamar Franco e os sucessivos dois mandatos de Fernando Henrique Cardoso, dois mandatos de Luiz Inácio Lula da Silva e, também, dois mandatos da presidente Dilma Vana Rousseff, sendo o último interrompido pelo golpe de 2016, que as reformas educacionais aconteceram bastante influenciadas pela lógica da 
educação liberal imposta aos países periféricos da globalização, sob o comando das Agências Internacionais. Os governos brasileiros foram respondendo às agendas educacionais do Banco Mundial, da ONU, da UNESCO, da OIT, da OEA etc., sem maiores resistências. Entre os governos do PSDB e do PT houve mais continuidades do que rupturas no atendimento da pauta educacional impositiva das Agências.

Há também diferenças e, algumas delas, segundo declarações teóricas de intelectuais da educação que subsidiavam as propostas do PT, apontavam para uma educação integral politécnica e emancipatória. Eu mesmo consultei textos que a página do MEC divulgava na internet expondo os fundamentos que pretendiam dar às reformas educacionais a serem implementadas. Em alguns governos estaduais estas propostas, em nível teórico, chegavam a ser mais intensas ainda. Os debates sobre o conceito de politecnia renderam muitos artigos, livros, teses, conferências e seminários. Na prática, quando se conseguiu estender a escolaridade de tempo parcial para tempo integral, em algumas experiências localizadas, pouco se sabia fazer à luz da proposta de educação politécnica e emancipatória porque ela se vincula e se alimenta em práxis sociais mais amplas, sustentada por uma visão de mundo e de homem radicalmente oposta ao atual status quo. Com mais tempo para a escolaridade dos alunos continuou-se a fazer mais do mesmo. Há exceções e por isso são lembradas. Penso que o grande equívoco ainda é acreditar que uma escola engessada pelos ditames da pauta educacional das Agências pode, como uma itha, propor uma pedagogia revolucionária. Ou seja, esta proposta não virá da instituição já normatizada, regulada e vigiada sob todos os ângulos. A escola estatal burguesa não pode acender uma vela para Deus e outra para o Diabo.

No caso brasileiro, penso que o que causa estranheza é: a socialdemocracia critica aspectos do capitalismo e continua liberal, portanto não alcança uma visão transformadora e revolucionária da educação e da sociedade. Aponta a educação politécnica emancipatória como alternativa no campo da educação escolar e não tem e nem cria condições objetivas de realizá-la. Também não banca por inteiro a educação integral liberal porque está a criticála e, por conseguinte, permanece na educação de tempo integral, a escola de maior tempo que, como dito, faz mais do mesmo. Acaba tudo em reformismo. Ainda assim, esta modalidade de escola é quantitativamente reduzida. Na verdade, ela se apresenta como alternativa para outras questões externas à educação escolar, por exemplo, para tentar evitar o crescimento da marginalidade infanto-juvenil, alimentar crianças em extremo estado de pobreza, liberar mão de obra feminina para o subemprego e o trabalho informal, dentre outras facetas cruéis da sociedade que vive sob o império do capital e da burguesia. Em outras sociedades capitalistas a educação integral de fundamentos liberais pode ter o desenvolvimento pretendido pela sua lógica. No Brasil, temos nossas especificidades. 
ACM: Professor, mediante sua análise sobre a conjuntura política nacional, que destinos podem-se esperar para a educação integral no país?

JLS: Os destinos para a educação integral politécnica e emancipatória, na atual conjuntura brasileira não são alvissareiros. Na conjuntura mais recente, os presidentes Temer e Bolsonaro se instituíram governantes por representarem forças muito reacionárias e de extrema direita. 0 primeiro comandou um profundo golpe contra as instituições democráticas com o apoio das Bancadas legislativas do Agronegócio, do sistema financeiro local/internacional e dos religiosos evangélicos. Se no golpe de 1964 o lema aglutinador de cooptação das camadas médias e populares foi o anticomunismo, em 2016 erigiu-se a anticorrupção, o antilulismo e o antipetismo como focos propagandísticos fundamentalistas. Analiso os golpes tanto no meu livro sobre a resistência ao golpe de 64 (SANFELICE, 1986), quanto num capítulo publicado recentemente (SANFELICE, 2017). 0 então candidato Bolsonaro, contando com maior anuência ainda das mesmas forças, somou-se à Bancada da Bala, teve a anuência militar de bastidores e, alicerçado em um extraordinário esquema de produção de fake news de um "comitê do ódio", transformou-se em o "Mito" e foi eleito presidente defendendo a ditadura, a tortura, a invasão das terras indígenas e agredindo os defensores do meio ambiente.

De 2016 a abril de 2020, agora em plena pandemia do Covid-19, não houve uma única medida de ação política legislativa ou do Poder Executivo que se possa comemorar como favorável às classes trabalhadoras. 0 Poder Judiciário se omite ou referenda, ou seja, tem sido cumplice. Nem os direitos fundamentais estão sobrevivendo ao terrorismo obscurantista avassalador. As Reformas Trabalhista e da Previdência, o desmonte do SUS, o congelamento e corte das verbas destinadas às políticas sociais convergem para a destruição e subjugação penalizadora das classes trabalhadoras. 0 desemprego, a pobreza, o precariado, a uberização e a falta de moradias avassalam milhões de pessoas. Outros milhões se encontram em estado absoluto de miséria. No campo da educação, a ideologização e partidarização do MEC e do CNPq, o sistemático ataque às Universidades públicas, o profundo desdém às ciências em geral e em especial às Humanidades, as tentativas que se ampliam de terceirização e privatização, - golpe da homeschooling, a reforma do Ensino Médio, a suspensão das bolsas para as pesquisas, a censura e a reescrita dos livros didáticos, enfim, avanços anteriores estão agora em processos de retrocessos e de destruição e, não necessariamente com alguma reposição seja lá de qualquer tipo. Simplesmente se desmontam as instituições. 0 projeto é de barbarização. A lógica é sempre liberal, neoliberal, mas a execução é sob a batuta da extrema direita que faz o serviço com requintes de humor. É só observar como Abraham Weintraub, já eleito como o pior Ministro da Educação da história, se refere ao emblemático educador Paulo Freire que é reverenciado como o Patrono da Educação Brasileira. Ou, então, quando ele menciona as Universidades Federais como lugares de balburdia e onde se faz plantações de maconha, para justificar o corte das verbas orçamentárias. Os docentes, pesquisadores 
e cientistas são submetidos a escárnios diários, e os alunos, juntamente com seus pais, são incitados a denunciarem os novos inimigos do povo que desejam difundir ideias e temas, segundo os novos algozes, ofensivos à boa formação da juventude e à qual o presidente recomendou que esqueçam da política. Veja-se a pauta do Movimento Escola Sem Partido. Os combatidos são genericamente chamados de comunistas.

0 muro das lamentações pode ser muito maior, mas não é disso que se trata. Reconhecer a adversidade da atual conjuntura é o ponto central da questão. Isto feito, cabe perguntar: Que destinos pode-se esperar para a educação integral no país? A escolaridade de tempo integral (ampliação da jornada do aluno na escola para fazer o mesmo do mesmo) ainda é uma realidade diminuta no cenário nacional. Está muito longe de se universalizar no ensino estatal da Educação Básica (infantil, fundamental e médio) e apresenta grandes diferenças regionais. É necessário, apesar de tudo, continuar exigindo a expansão do modelo porque ele tem algumas implicações práticas no cotidiano da vida da classe trabalhadora e porque $\circ \mathrm{EaD}$ e o homeschooling provavelmente agravem a situação. A educação integral liberal, como definida anteriormente, está mais presente em instituições escolares privadas e, de alguma forma, em instituições públicas de ensino técnico médio ou superior. A tendência conjuntural é que continue se ampliando mesmo que aos trancos e barrancos. As classes médias e frações das classes populares têm sido o seu público e, portanto, não pode ser jogada pela janela. A burguesia cuida da educação dos seus filhos seguindo caminhos próprios, como bancando colégios altamente seletivos caríssimos e estudos fora do país. Para nada nos importa isso, embora muito da educação de que se apropriam também venha a nos ser útil e para outras finalidades. A educação integral politécnica e emancipatória é ainda uma utopia, um ideário em alimentação, uma proposição convicta e que será construída no embate infindável no cotidiano escolar, na escola que já existe e que, nas suas entranhas contraditórias apresenta os espaços para a luta. É apenas uma faceta da pugna política mais geral por uma sociedade qualitativamente superior a atual.

ACM: Professor, não podemos perder a esperança nas possibilidades transformadoras dos processos educativos, mas nas condições atuais, como oxigenar o fogo dessa esperança? E em que consiste a sua esperança, em termos educacionais?

JLS: Eu concordo. Não podemos perder as esperanças nas possibilidades transformadoras dos processos educativos. Falei várias vezes em utopia. Referi-me à utopia de se construir uma sociedade qualitativamente superior a atual e, também, da utopia que alimenta o ideal de uma educação integral politécnica e emancipatória. É preciso dizer que a utopia não é um motivo para a simples contemplação empática de algo que ainda não existe. Ela é, antes de tudo, um poderoso instrumento crítico do que existe e se quer transformar. Ao se desenhar o que não existe e se reconhecer naquele ideal, começamos a nos mover, 
na prática, para lá. A capacidade de ideação humana transcende as nossas contingências materiais.

Um dia se desejou chegar à lua. Depois de séculos e após inúmeras teorias, as condições materiais (ciência, tecnologia, instrumental) viabilizaram o inusitado. As utopias surgem no interior das práticas sociais e são alimentadas pelo desejo de transformá-las. Não são sonhos evasivos, mas ideários libertários para além da nossa imanência. Não são invenções arbitrárias, pois nascem na materialidade do que se vivencia e se deseja negar, para incorporar de forma transformadora e superar. A forma dialética de pensar permite captar tal dinâmica.

Por outro lado, como as utopias atrapalham o poder constituído e aglutinam adeptos na coletividade humana, elas precisam ser combatidas, rechaçadas, desacreditadas, censuradas, ridicularizadas e perseguidas. Na melhor das hipóteses são consideradas ideias mortas de alguns sonhadores pré-históricos. Na contramão das utopias surgem as afirmações sobre a morte delas e se produzem as posturas distópicas que se contrapõem para arrefecer os ânimos dos insatisfeitos, para naturalizar o status quo e desenvolver o conformismo continuísta que tão bem serve à classe social que já construiu o seu paraíso celeste por aqui. Que as demais classes sociais acreditem numa salvação após a morte e não desenvolvam práxis construtivas alimentadas pelos ideais utópicos. Mas, a esperança militante é que as utopias nascidas imersas na negação de uma sociedade existente, alimente a práxis consequente da transformação dela. Então, de onde partir?

Em termos educacionais, partir da escola estatal existente. Isto implica a defesa dela na luta contra os avanços da privatização. Não vamos inventar uma escola partindo do nada, paralela à existente, ou aguardar que um dia a mudança revolucionária da sociedade inicie o processo de uma nova educação. No pós-revolução a conversa é outra. Aqui e agora é preciso implementar ao máximo a universalização da escola estatal em todos os níveis e modalidades de ensino. As políticas públicas têm que ser pressionadas por todos os cidadãos para que elas caminhem nesta direção e sejam artífices eficazes dos recursos públicos necessários.

A laicidade efetiva da escola estatal não pode retroceder um milímetro. As tentativas de assédio à escola estatal, por parte das igrejas, têm que ser banidas de vez. As frestas existentes para uma gestão mais democrática e participativa necessitam ser escancaradas com a ocupação de cada espaço dentro da instituição escolar. É fundamental fortalecer conselhos, associações, grêmios e diretórios escolares. A igualdade de acesso e permanência dos alunos no processo de escolaridade tem que ser garantida por uma profunda compreensão da diversidade da origem social deles. Sem levar em conta tal dimensão, o discurso da igualdade de oportunidades sempre será uma ficção. 0 compromisso com a maior democratização possível do conhecimento socialmente disponível é algo fulcral. 
Isto posto, qualquer censura ao conhecimento é inadmissivel, portanto há que se ter grande discernimento na escolha do material didático-pedagógico a ser utilizado recusando-se as imposições, a proibição de temas e a perda da autonomia docente. É, na prática, um grande confronto em torno da disputa por um currículo voltado à formação para a vida e do mais profundo significado do papel do docente. Muitos outros aspectos podem ainda ser enumerados, mas fico por aqui. Aos partidos de esquerda revolucionária cabe assumirem em seus programas a luta no campo específico da educação e se tornarem orgânicos no sentido de implementarem todos os movimentos sociais (de docentes, do movimento estudantil, dos trabalhadores em educação, dos pais de alunos etc.) para o avanço da causa. Sem organicidade também não é possível caminhar e corre-se o risco de se mergulhar em procedimentos individuais voluntaristas. A tarefa tem que ser coletiva e não será facilitada ou oferecida pela estrutura estatal que controla a escola hoje. Temos que estar lá dentro da instituição e aliados ao público que a frequenta para travarmos o combate. Confio muito nos educadores, pois apesar de todas as adversidades, eles sabem que sem utopias não se constituem em agentes formadores e, sim, permanecem profissionais automatizados. 0 movimento docente também precisa refazer-se com uma pauta para além de associativa corporativa. Usando uma linguagem bíblica e adaptada, temos que nos constituir no trigo que se mistura ao joio para eliminá-lo. Ou, então, a imagem que vem da militância: se o cupim não estiver dentro do toco, o toco não vai ruir.

Quanto ao ideal de uma educação integral politécnica e emancipatória, conhecemos mais as teorias que a embasam do que as práticas que a materializem de forma ampla. É possível que as tentativas mais efetivas para implementá-la tenham sido aquelas realizadas na ex-União Soviética, quando no seu período revolucionário no início do século XX. Não é possível supor sua configuração extensiva no âmbito das sociedades de modo de produção capitalista. Primeiro, porque ela propõe uma ontologia do humano inconcebível no âmbito do pensamento liberal ou neoliberal. Os homens são concebidos como portadores de uma existência que constrói a sua própria essência, ou seja, não são herdeiros de uma essência absoluta de qualquer natureza. Constituir-se em humanos é o desafio da própria espécie. E, é a historicidade da espécie que demonstra isso por milênios afora. Numa expressão de caráter existencialista pode-se dizer que estamos condenados a nos fazer humanos.

Todos os processos de ensino-aprendizagem que a humanidade desenvolveu ao longo dos tempos (educação informal, formal e escolar de múltiplas instituições - igrejas, escolas, clubes, exército, cadeias etc.), teoricamente e com grande dimensão também prática, visaram preservar a espécie e viabilizar a sociabilidade pelo menos razoável entre os seus indivíduos. É fato que nem sempre prevalecem atitudes consideradas aceitáveis pelo atributo que nos impusemos de racionais. A irracionalidade não deixa de se fazer presente e segundo os nossos próprios critérios do que é ou não racional. 
Ao nascerem, as crianças sugam os peitos das suas mães pelo instinto da sobrevivência, como os demais mamíferos. E a caminhada de se fazer humano, sociável, dá sequência à vida antes uterina. Pesam, demasiadamente, as determinações das circunstâncias: ninguém escolhe seus pais biológicos, seu sexo, sua primeira língua, seu nome de batismo, a iniciação religiosa, a classe social e outras tantas condições. Mas, em todos os momentos da vida e, sempre dependendo de outros condicionantes, pode-se optar entre sexualidades diversas, aprender uma segunda ou mais línguas, alterar seu nome de batismo, mudar de religião ou simplesmente abandoná-la e, algo bem mais difícil, transferir-se de uma classe social para outra.

Todas estas considerações foram feitas para dizer que uma educação integral politécnica e emancipatória tem que se assentar nos fundamentos da existência e da essência que a humanidade constrói coletivamente. É, portanto, uma concepção de educação imanente, é o nosso desafio para com nós mesmos. Por outro lado, contém a transcendência da construção contínua de libertação face aos condicionantes de toda ordem. Pauta-se pelo imperativo de fornecer aos sujeitos todos os recursos possíveis para que ele vivencie a própria vida de forma plena e integral, juntamente com o seu coletivo. 0 princípio da igualdade natural e real entre os homens antecede a qualquer outro que resulte da ordem sociocultural. Os sujeitos não são iguais perante a Lei, mas são iguais perante a si mesmos. A Lei deve servir para garantir tal evidência quando se vacila na prática e por conta do que temos de irracionalidade. E para que? Para não nos reduzirmos ao mundo animal e, uma vez que, construímos e acumulamos um mundo também cultural. É a proteção da espécie em sua primeira e segunda naturezas. Portanto, a educação integral politécnica e emancipatória só se sustenta como uma busca contínua de liberdade. Somente uma postura revolucionária pode comprometer-se com ela. Traduz-se na busca de uma formação humana que recusa as desigualdades de toda ordem e a exploração de uns sobre os outros nas múltiplas dimensões das nossas relações sociais. 0 trabalho é a ação humana de sobrevivência por excelência, pois por meio dele se transformam a natureza e a cultura pré-existentes, para que atendam as nossas necessidades que se atualizam nos tempos.

Considerando o aviltamento do trabalho nas diferentes formas históricas nas quais se constituiu após a diluição das comunidades primitivas (escravidão, servidão e trabalhador "livre", não de forma necessariamente sucessiva), o resgate da sua libertação dos grilhões da exploração executada no trabalho alienado é a grande prioridade. Entende-se, assim, a máxima revolucionária de caminharmos de um trabalho aprisionado pelas necessidades para um trabalho no mundo da liberdade. A libertação do trabalho e dos trabalhadores do jugo do capital é a meta radical da educação emancipatória. Então, ela não pode ser apenas para o desenvolvimento de habilidades e preparação para as exigências de mercado. Ela não pode se reduzir meramente a uma dimensão técnica ou conformadora dos homens a um destino que se thes impinge, supostamente em consonância com as competências inatas de cada 
um. A educação integral emancipatória tem que se organizar, portanto, em torno do princípio que reivindica a libertação do trabalho e do trabalhador face ao capital a ser subsumido juntamente com a classe social que dele se alimenta. E, isso, implica em uma concepção de prática educacional politécnica a ser construída desde já e na contramão da escola estatal burguesa que se encontra cada vez mais esvaziada de conhecimentos imprescindíveis.

Sobre o conceito de politecnia, muito já se escreveu. Posso, então, sintetizar o que se tem de consensual. Trata-se de uma educação intelectual, corporal e tecnológica. Intelectual num sentido bastante amplo e que deve contemplar o estudo das humanidades, da literatura e das artes. São conhecimentos necessários e fundamentais na formação de uma visão científica e crítica da história da humanidade e de todas as relações humanas em construção. Deve fundamentar a formação moral que privilegia princípios de liberdade, igualdade, fraternidade solidária e justiça irrestrita em perspectiva universal. Sua pedagogia incorpora, de forma vivencial, as expressões da manifestação de transcendência humana pela filosofia e todas as artes. Reconhece que todos os homens são filósofos e devem poder filosofar, bem como usufruir do acesso indiscriminado ao acervo cultural geral disponibilizado pela humanidade.

Os nossos sentidos necessitam ser socialmente educados, caso contrário, a mais bela música não será percebida por ouvidos moucos ou a mais bela joia não será apreciada pela sua dimensão estética, mas apenas quanto ao valor mercadológico do ouro. Além disso, a educação corporal deve nos formar para a capacidade física do trabalho e o desfrutar das atividades de lazer, dentre elas os exercícios físicos e as práticas esportivas. 0 cultivo da saúde corporal é essencial para se garantir a saúde mental. 0 nosso corpo pensa, se entristece, alegra-se, se fatiga e é fonte de grandes prazeres. Precisamos ter muitos carinhos para com ele, pois nele está a nossa única possibilidade de ser.

A dimensão tecnológica da politecnia deseja explicitar a necessidade da formação no campo das ciências "puras", naturais e biológicas. Implica ainda o conhecimento e o saber manusear as tecnologias e os instrumentais existentes. Não é uma dimensão paralela ou justaposta à formação intelectual. Ambas precisam caminhar imbricadas. Por exemplo, qualquer tecnologia tem o histórico da sua produção; houve um contexto que viabilizou a sua emergência e ela emana sempre das necessidades objetivas que se manifestam no interior de relações sociais específicas. Quando no mundo do trabalho o trabalhador se reduz a um operador de técnicas e instrumentos, sem o conhecimento teórico do conjunto da operação, sua humanidade esvai-se. Torna-se mero técnico treinado para responder e corresponder à tecnologia e ao instrumento nos quais está inserido. A educação tecnológica não politécnica prima por separar trabalhadores que possuem os conhecimentos teóricos dos trabalhadores que executam as atividades práticas. Não é característica da sociedade de modo de produção capitalista aglutinar conhecimentos teóricos com conhecimentos práticos. 
A formação tecnológica politécnica é o oposto. Defende incondicionalmente a junção da teoria e a prática, sendo também chamada de omnilateral, em oposição à educação unilateral que subsidia o trabalho alienado. A formação tecnológica politécnica, de "per si" não resolve a questão do trabalho alienado, mas é uma condição fundamental no processo de um projeto revolucionário, pelas consequências que traz para a formação da classe trabalhadora.

Minha esperança? Sim, ela existe, mesmo que eu não viva para assistir a sua materialização. Somente as classes trabalhadoras podem desejar a liberdade, a igualdade, a fraternidade solidária e a justiça em caráter universal. Não sou eu que quero que assim seja. É o desenrolar da história que nos dá a certeza. Pode ocorrer uma fatalidade pela qual a espécie humana desapareça e, talvez, provocada por si mesma. Aí, sim, será o fim da história, pelo menos da história à qual nos referimos. Se assim não for, as mudanças continuam acontecendo e o modo de produção capitalista refaz suas possibilidades de sobrevivência a cada dia. Não esgotou ainda todas as suas possibilidades.

As contradições intrínsecas, entretanto, demonstram que há um ponto previsivel de desmoronamento estrutural e por conta de várias evidências, como por exemplo, as riquezas mundiais concentram-se cada vez mais em mãos de um reduzidíssimo número de pessoas ou famílias; o esgotamento das explorações dos bens materiais e naturais, com profundas implicações ambientais e ecológicas já anunciam suas consequências dramáticas às sociedades globais; o número de desempregados cresce mundialmente; os trabalhadores estão sendo precarizados incondicionalmente pela nova revolução tecnológica e a imposição de relações ainda mais exploratórias do que antes. São mantidos em limites imensuráveis de expropriação e com a perda de direitos básicos e essenciais.

Mesmo com as ressalvas teóricas que se faz presentemente ao conceito de classe social, pergunto: Quem poderá se levantar hoje contra a opressão do capital senão a classe trabalhadora empregada, desempregada, precarizada ou tudo que se assemelha a ela? É possível esperar alguma condescendência do capital e da burguesia? Enfim, do ponto de vista da história, todos os modos de produção ruíram ao constituírem, no seu interior, as condições que viriam superá-los. 0 próprio capitalismo não surgiu em paralelo ao feudalismo, mas no interior dele e até que se viabilizasse numa subversão revolucionária burguesa. Um dia a burguesia se viu com a necessidade de mandar para o além reis, nobres e religiosos. Assim o fez e graças a ela as sociedades europeias se libertaram da servidão. A história não se repete, mas a busca de liberdade faz parte do nosso transcender que se aguça frente ao mundo de opressão.

No campo da educação minhas esperanças se voltam principalmente à classe trabalhadora que atua na área, indistintamente para todos os que se encontram em diferentes níveis e funções. Mas, deposito especial atenção nos docentes por conta da posição estratégica que ocupam na instituição escolar. Somos alguns milhões atuando junto 
a outros milhões de alunos e com eles passamos também milhões de horas dias após dias. Nosso poder de influência e persuasão pedagógica, inclusive sobre as famílias dos alunos, é infinito.

Precisamos avançar enquanto classe trabalhadora. Nossas reivindicações corporativas são muitas e legítimas, seja por piso salarial, melhores salários, concursos públicos, carreira docente, condições materiais de trabalho, segurança e principalmente formação. A formação, há décadas, vem sendo vilipendiada. Faz parte da crise como projeto e não como crise, já referida acima.

Não é possível vincularmo-nos aos princípios da educação integral politécnica emancipatória, sem repensarmos toda a formação dos educadores, sua visão de mundo, sua visão de homem, sua compreensão do trabalho como fonte de libertação. Uma tarefa nossa é investir numa sólida organização da categoria. Apesar da crueldade com que a fração de classe trabalhadora, os educadores, são tratados nas condições atuais, a situação não é pior e nem melhor do que a maioria de todos os demais trabalhadores. Temos que nos unir a eles e não esperar que venha algo do Estado, o patrão de muitos de nós, em nosso favor.

Nosso compromisso último não é com o Estado, mas com os cidadãos que pagam os nossos salários e se encontram no mesmo barco de explorados. Essa identidade nos une em torno da mesma utopia e o educador desprovido de utopias é apenas um reprodutor do status quo. A nossa consciência crítica e omnilateral tem que ser construída na luta cotidiana e, assim, se impõe o novo conceito de cidadania. Sim, estamos frontalmente em oposição ao pensamento liberal e neoliberal, seja na educação ou nas relações sociais agora estabelecidas. Não importa os adjetivos que costumam nos atribuir: esquerdistas, marxistas, socialistas, comunistas, anarquistas ou, como está na moda brasileira de inspiração conspiracionista, lulistas e petistas. 0 que realmente importa e incomoda é a possibilidade de um novo projeto de uma sociedade superior à atual.

Agradeço imensamente ao professor Dr. José Luís Sanfelice por esta oportunidade e pela gentil condução da entrevista.

\section{REFERÊNCIAS}

MACIEL, A. C.; SILVA, C. A.; FRUTUOSO, C. 0 conceito de educação integral e as possibilidades da educação integral politécnica em Manaus. Práxis Educacional. Vitória da Conquista, BA, v. 15, n. 32, p. 174-204, abr./jun. 2019.

RIBEIRO, D. Nossa escola é uma calamidade. Rio de Janeiro: Salamandra, 1984.

SAFELICE, J. L. Com o golpe de 2016, para onde caminhará a educação? In: LUCENA. C.; PREVITALI. F. S.; LUCENA, L. (org.). A crise da democracia brasileira. Uberlândia, MG: Navegando, 2017. p. 261-278. 
SAFELICE, J. L. Movimento Estudantil - A UNE na resistência ao Golpe de 64. São Paulo: Cortez, 1986.

Endereço para correspondência: Departamento de Ciências Sociais, Universidade Federal de Rondônia, Campus José Ribeiro filho, BR 364, KM 9,5 (Sentido Rio Branco), 76801-059, Porto Velho, Rondônia, Brasil; maciel_ac@hotmail.com 
